\title{
Two Dimensional Dam Break Flow Study Using HEC-RAS for Ujjani Dam
}

\author{
Mrunal M. Joshi ${ }^{\# 1}$ S. S. Shahapure ${ }^{\# 2}$ \\ \#1 Civil Engineering Department, Rajarshi Shahu College of Engineering, Tathawade, Pune 411033, India. \\ \#2 Civil Engineering Department, Rajarshi Shahu College of Engineering, Tathawade, Pune 411033, India. \\ 1'mmjnbn@gmail.com, 2drssshahapure@gmail.com
}

\begin{abstract}
Dams are beneficial for society but flood occurs due failure of dam is dangerous for lives, properties and Environment. Prediction of dam break flows is necessary for forecasting and evaluation of flooding disaster and preparation of an emergency action plan. In this study dam break flood routing simulation is carried out by using HEC-RAS two dimensional model for Ujjani dam to determine Flood Susceptible area at the downstream side of dam considering Pandharpur city as study area.
\end{abstract}

Key Word- Flood, Flood routing, Flood mapping, Dam Break, HEC-RAS 2D model.

\section{INTRODUCTION}

Dam is barrier constructed across the river to store the water. This stored water is useful for Domestic purpose, Irrigation, Industrial use, Navigation etc, but flood occur due to dam failure always dangerous for society, so it is necessary to analyze flood wave propagation at the downstream side of dam for evaluation of flooding disaster. Dam Break Analysis is useful to identify the inundated area, flood depth, flood velocity and travel time of flood waves.

Dam break analysis is carried out for following reasons-

- $\quad$ Preparedness to tackle the disaster

- $\quad$ Preparation of inundation map

- Preparation of evacuation plans

- Evaluation of the risk at downstream of dam failure

- Emergency plans for reinstatement of infrastructure

- Design of protection measures.

\section{LITERATURE REVIEW}

Dam-break flows can be studied by analytical, numerical and experimental methods. In practice, few raw data on dam-break flows are available due to the unpredictability of disasters. Dam Break study was started in 1850s in France. From 1850 to1950 there were no computers so the dam break study was focused on finding theoretical solutions and physical model test. From 1950 to1990 study was focused on study of factors responsible for dam break and flooding disaster at downstream of dam. From the period of 1990 to till date study is focused on dam safety analysis. [1]

Most widely used tools for Dam break study are the National Weather Service (NWS) Dam-Break Flood Forecasting Model (DAMBRK); the U.S. Army Corps of Engineers Hydrologic Engineering Center Flood Hydrograph Package, HEC-1 (Hydrologic Center, 1981); and the NWS Simplified Dam-Break Flood Forecasting Model, SMPDBK (Wetmore and Fread, 1983). Of these models, DAMBRK was the most widely used. The National Weather Service released FLDWAV (Fread, 1993), the successor to DAMBRK. Mike11 and HEC-RAS are also useful tools for this exercise. [2]

From literature study, in India dam Break failure was occurred at three places. In 1917 at Gwalior, India Tigra dam failed due to water infiltrating through foundation. In 1961 at Pune, India Panshet dam was burst due accumulated rain water. In 1979 at Morbi Gujarat, Machchu Dam-2 was failed due to heavy rain and flooding beyond Spillway capacity. [3]

\section{METHDOLOGY}

US Crops Army’s Hydrologic Engineering center's River Analysis System (HEC-RAS) simulation model is used for dam break analysis study of Ujjani dam in Solapur district, Maharashtra, India. HEC-RAS two dimensional model is powerful yet to easy to use software for determining water depth, discharge, inundation area, and flood wave velocity \& water surface profile in two dimensions.

Analyzing of failure of dam is two steps process. 1) Analysis of actual breach of dam. 2) The outflow from the breach must be routed through the downstream valley to determine the resulting flood at population centers.

From literature review we can state that majority cases of earthen Dam failure are due to Overtopping. 


\section{A. Overtopping Failure}

In overtopping failure water flows over the crest of dam. Head cut erosion starts from the downstream side of dam embankment. When cut reaches to upstream of dam mass failure will occur. [4]

\section{B. Breach Parameters}

Breach parameters include breach width, breach depth, side sloping angles \& breach time. In the study dam break analysis is carried out for worst condition to determine flooding area at downstream side of dam for Pandharpur city, so breach parameters are taken to get maximum breaching of dam and peaked out flow from breached dam is taken considering full reservoir discharge. [5]

\section{Data Collection}

Ujjani dam is constructed across Bhima River at Bhimanagar in Solapur district.

1) Toposheet from Survey of India Pune Toposheet Nos. - $47 \mathrm{O} / 1,47 \mathrm{O} / 6,47 \mathrm{~N} / 4$

2) Digital Elevated Model (DEM) from Indian Geo-platform of ISRO, Bhuvan (www.nrsc.gov.in) with $30 \mathrm{~m}$ resolution and WGS 84 datum and UTM projection.

3) Land use / Land cover classified satellite map of Study area from National Remote Sensing Center (www.nrsc.gov.in)

4) Discharge data of Ujjani Dam from

i) Sub-divisional office Bhimanagar,

ii) Bhima patbandhare vibhag Pandharpur

iii) Irrigation department of Pune.

5) Discharge data of Veer dam from Irrigation department of Pune.

6) Geometrical information of Bhima river Basin from Solapur catchment development Authority (CADA).

TABLE NO.I Dam Details

\begin{tabular}{|l|l|}
\hline Name of Dam & Ujjani Dam \\
\hline River & Bhima River \\
\hline Nearest City & Baramati , Solapur \\
\hline Basin Name & Krishna basin \\
\hline Dam Type & Earthen / Gravity \\
\hline Dam height & $54.60 \mathrm{~m}$ \\
\hline Top of Dam (RL) & $501.40 \mathrm{~m}$ \\
\hline Dam length & $2534 \mathrm{~m}$ \\
\hline Top width of Dam & $6.70 \mathrm{~m}$ \\
\hline No. of Gates & 41 \\
\hline Gate type & Radial gate \\
\hline Gate size & $12 x 6.5 \mathrm{~m}$ \\
\hline Weir Shape & Ogee \\
\hline Spillway Type & Concrete \\
\hline
\end{tabular}

HEC-RAS 5.0.1 (2D) Model is used to create simulation for analyzing flood susceptible area of Pandharpur Region, Solapur District, and Maharashtra. Two-Dimensional Unsteady flow analysis is carried out for Dam break analysis and to determine the resulting flood at downstream side of Dam. Unsteady Flow Analysis method used with Implicit Finite Volume algorithm and Wave Diffusion equations. [6]

\section{Dam Break Analysis for Ujjani Dam}

Digital Elevation model (DEM) from Indian Geo-platform of ISRO, Bhuvan (www.nrsc.gov.in) with 30m resolution and WGS 84 datum and UTM projection is used. Land use / Land cover classified satellite map of LISS-III sensor, $30 \mathrm{~m}$ resolution resource sat II satellite data, from National Remote Sensing Center (www.nrsc.gov.in) is used.

From DEM Terrain Model was created. 


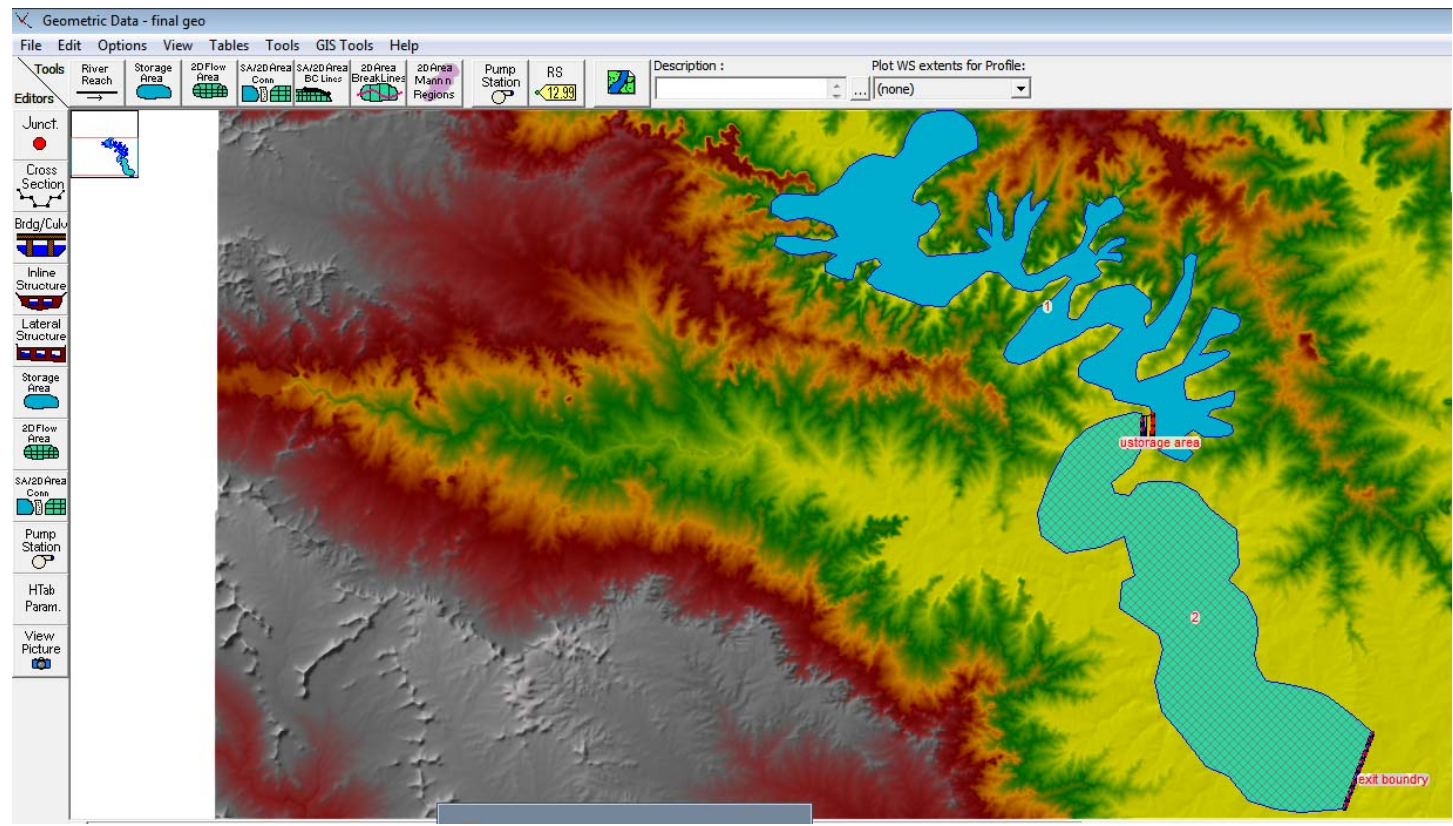

Fig.. No. 1 Geometric data of Ujjani dam

After creation of Terrain model, 2D flow area boundary and Storage area boundary were marked and then mesh formation was done.

Boundary conditions - $\quad$ 1) Storage area -2d Flow area connection

2) Exit boundary- Normal Depth

3) Lateral Flow

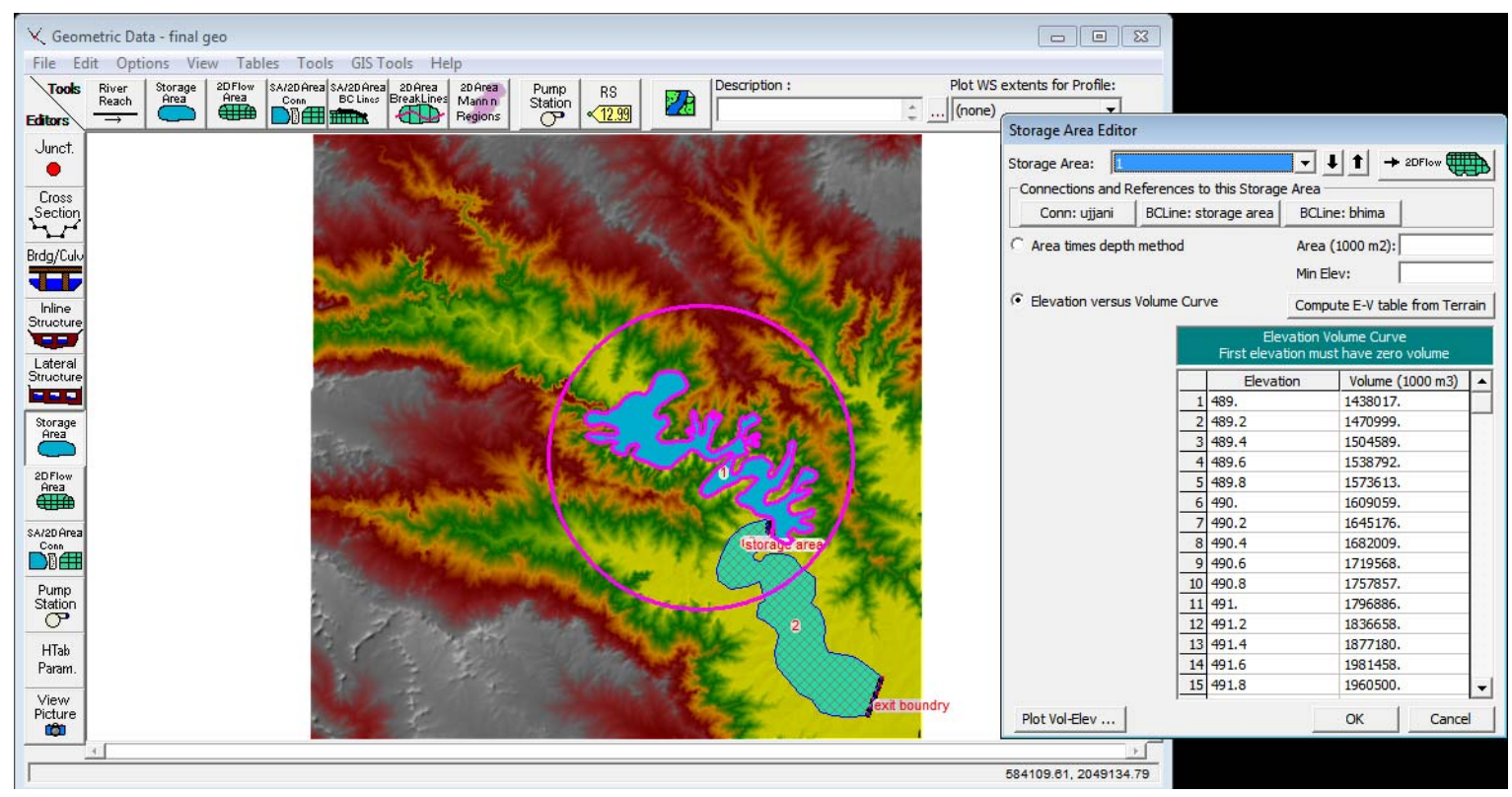

Fig. No. 2 Elevation Volume curve-Ujjani dam 
TABLE NO II Storage Capacity of Ujjani Dam

\begin{tabular}{|l|l|l|l|l|l|}
\hline $\begin{array}{l}\text { Elevation } \\
(\mathbf{M})\end{array}$ & $\begin{array}{l}\text { Volume } \\
(\mathbf{1 0 0 0 M})\end{array}$ & $\begin{array}{l}\text { Elevation } \\
\mathbf{( M )}\end{array}$ & $\begin{array}{l}\text { Volume } \\
(\mathbf{1 0 0 0 M})\end{array}$ & $\begin{array}{l}\text { Elevation } \\
\mathbf{( M )}\end{array}$ & $\begin{array}{l}\text { Volume } \\
(\mathbf{1 0 0 0 M 3 )}\end{array}$ \\
\hline 489 & 1438017 & 492 & 2003313 & 495 & 2751633 \\
\hline 489.2 & 1470999 & 492.2 & 2046905 & 495.2 & 2809488 \\
\hline 489.4 & 1504589 & 492.4 & 2091987 & 495.4 & 2868338 \\
\hline 489.6 & 1538792 & 492.6 & 2136465 & 495.6 & 2928192 \\
\hline 489.8 & 1573613 & 492.8 & 2142447 & 495.8 & 2989058 \\
\hline 490 & 1609059 & 493 & 2229239 & 496 & 3050944 \\
\hline 490.2 & 1645176 & 493.2 & 2276932 & 496.2 & 3113925 \\
\hline 490.4 & 1682009 & 493.4 & 2325618 & 496.4 & 3178076 \\
\hline 490.6 & 1719568 & 493.6 & 2375308 & 496.6 & 3243406 \\
\hline 490.8 & 1757857 & 493.8 & 2426008 & 496.8 & 3309926 \\
\hline 491 & 1796886 & 494 & 2477738 & 497 & 3377450 \\
\hline 491.2 & 1836658 & 494.2 & 2530474 & 497.2 & 3446012 \\
\hline 491.4 & 1877180 & 494.4 & 2584225 & 497.4 & 3515704 \\
\hline 491.6 & 1981458 & 494.6 & 2638996 & 497.6 & 3586536 \\
\hline 491.8 & 1990500 & 494.8 & 2694795 & 497.8 & 3658516 \\
\hline
\end{tabular}

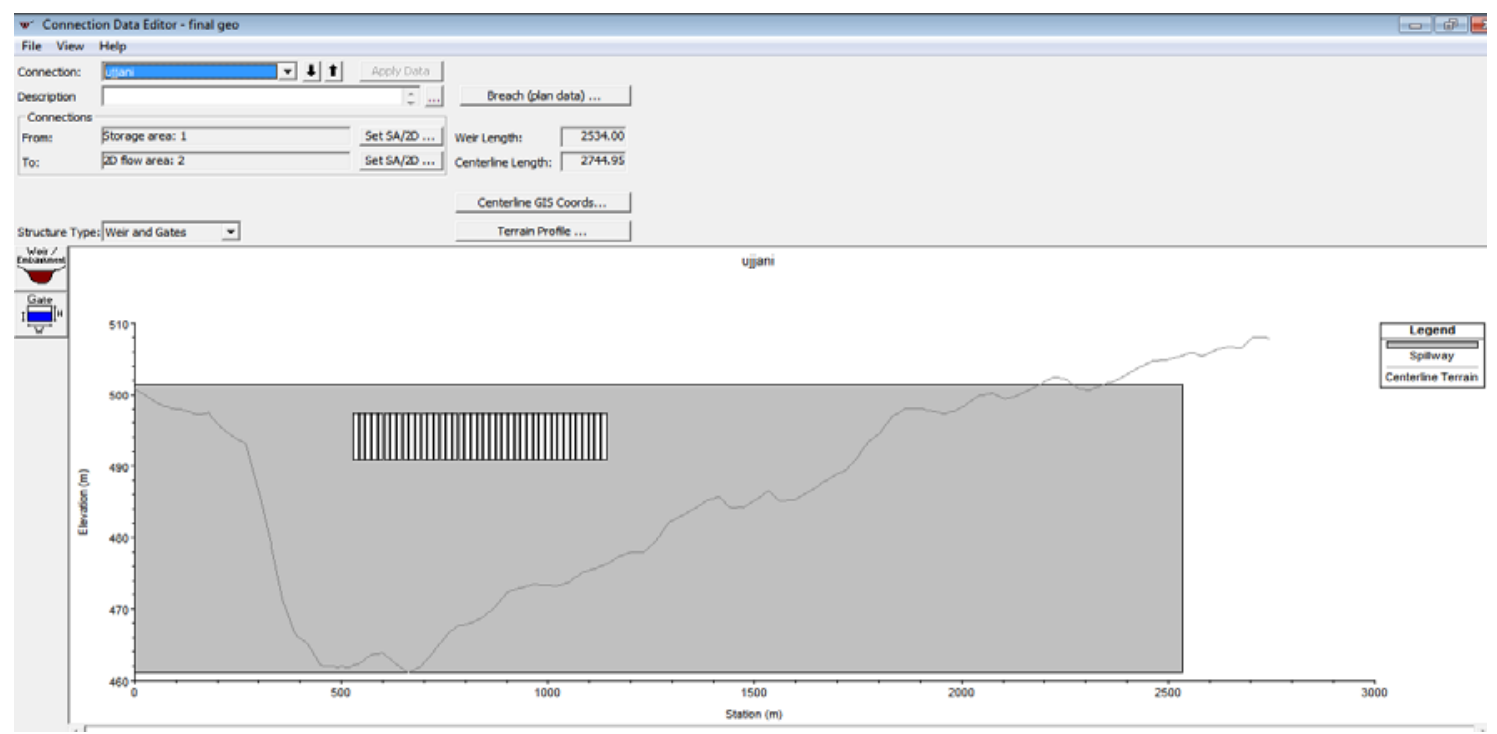

Fig. No.3 Ujjani Dam- Weir \& Gates details

E. Breach parameters

Breach Width- 1000m

Breach bottom Elevation-800m

Left side slope-1:20

Right side slope-1:50

Breach time- 6 minutes. 


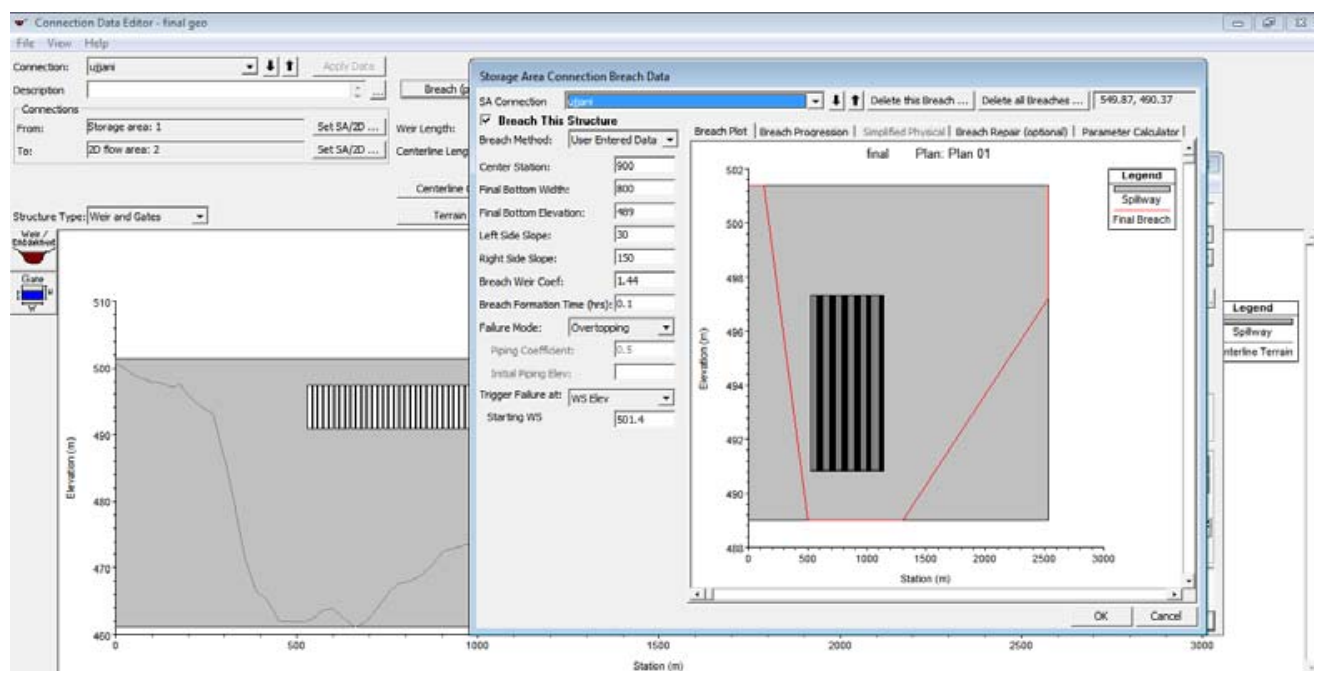

Fig. No.4 Breach Details- Ujjani Dam

\section{RESULT}

Unsteady flow simulation is carried out for dam breach study. Hydrograph output interval taken as one hour, computational interval taken $15 \mathrm{sec}$. Ujjani dam failed at lateral flow discharge $41000 \mathrm{~m}^{3} / \mathrm{sec}$. Following area is under flooding.

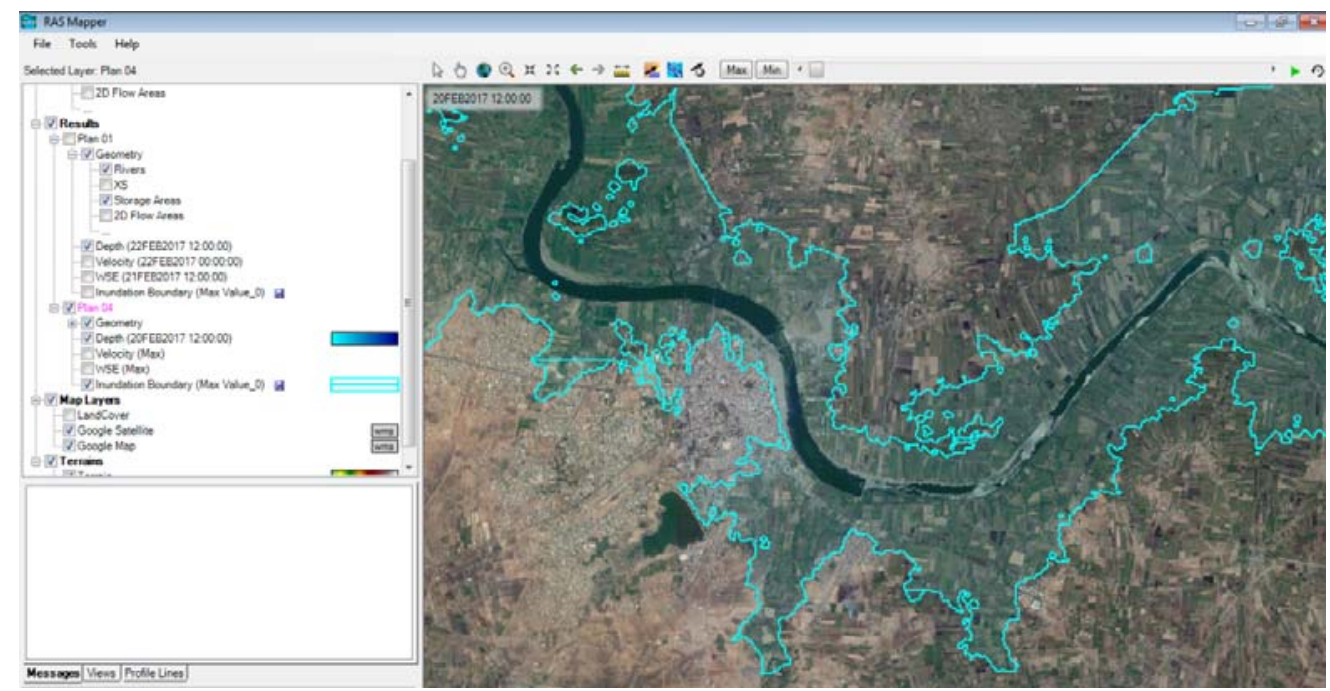

Fig. No.5 Inundation map

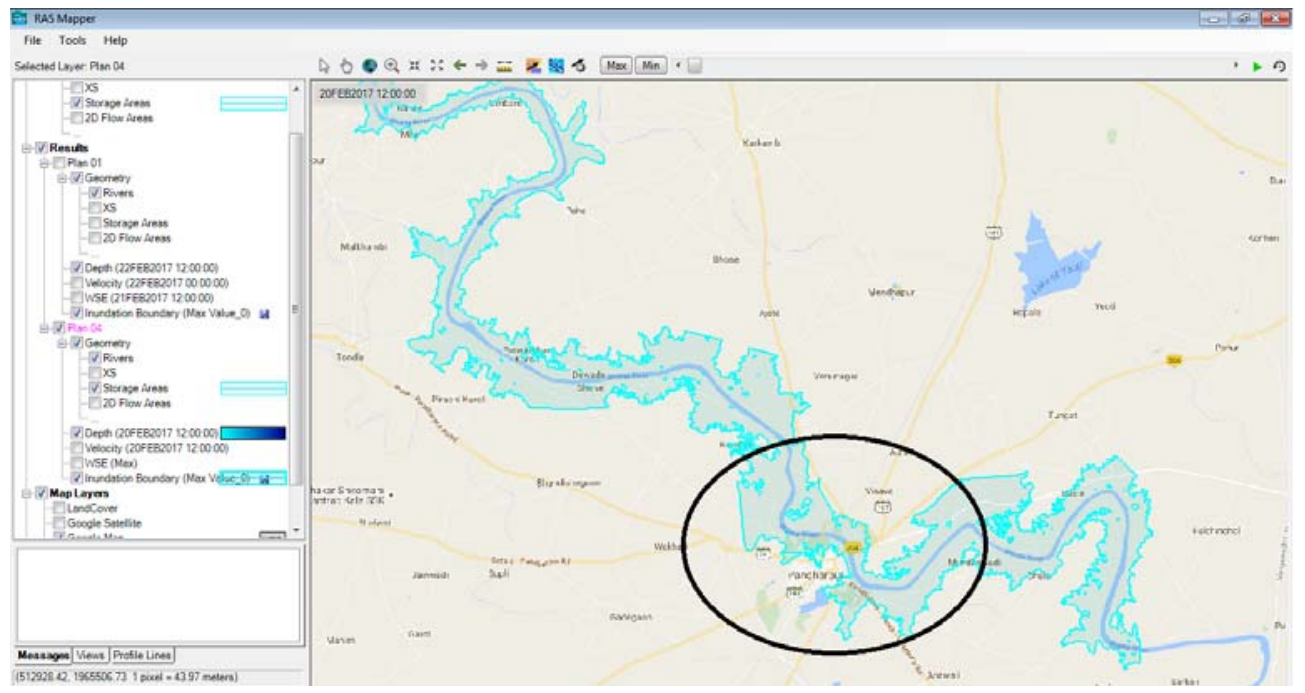

Fig. No. 6 Inundation map 
Due to dam break Vishnupad temple, Rajani Road, Pandharpur Madhewadi Road, Visthapit Nagar Area, June Pat area, Kaikadi Maharaj temple, ISKCON area Pandharpur, Gopalpur Naka, Bhakti Marge, Shri Pundlik Mandir, Durga Mandir, Wadar Ghat area, Govinpura Ghat slum area, Datta Ghat slum Area, Kumbhar Ghat Slum Area, Chandrabhaga Ghat area are under flooding.

\section{CONCLUSION}

Study area Pandharpur city is having more importance as it is one of famous pilgrim center so floating population percentage is more, reported by Pandharpur Municipal Council following number of pilgrims are coming besides town population of about one Lac twenty thousand. (Sub Regional Office, Solapur and Regional Office Maharashtra Pollution Control Board PUNE, August 2005)
A) Normal period
i) Daily pilgrims: 10,000
B) During Ekadhashi
i) 15 days ekadhashi: 25,000
ii) Monthly ekadhashi: 50,000
C) During Waries (Yatra)
i) Chaitra - 3-4 lakhs (10 days)
ii) Ashadhi: -10-12 lakhs (15 days)
iii) Kartiki: - 8-10 lakhs (15 days)
iv) Magh: - 3-4 lakhs (10 days)

In view of large number of people visiting the area every year during four important yatra festivals there is need to plan the city with infrastructure to take the shock of lodging. Flood-prone areas are occupied either legally or illegally for the purposes of human settlement. Loss of life due to flooding could be more compared to other area as Ashadhi wari (June-July) is during the rainy season. Adverse effects of such floods can be minimized by proper planning and future development if the occurrence of floods and magnitude of flood can be predicted and managed systematically. So this study will helpful to local planning authority for taking appropriate decision.

\section{REFERENCES}

[1] Luo You, Chen Li, Xu Min, Tong Xiaolei, "Review of dam-break research of earth-rock dam combining with dam safety management” International Conference on Modern Hydraulic Engineering, State Key Lab of Water Resources and Hydropower Engineering Science, Wuhan University, Wuhan, 430072, China, 2012

[2] Fread, D.L., "BREACH: An Erosion Model for Earthen Dam Failures", National Weather Service, Office of Hydrology, Silver Spring, Maryland. 1988 (revised 1991).

[3] Abimael Leoul Zewdiea "Dam Breach Analysis Using HEC-RAS and HEC-GeoRAS: The Case of Kesem Kebena Dam” December, 201

[4] Brunner. "Using HEC-RAS for Dam Break Studies”. U.S Army corps of engineers Hydrologic Engineering Center (CEIWR-HEC) 609 second street, Davis. (2014).

[5] Wahl, T. L. Prediction of Embankment Dam Breach Parameter. U.S. Department of the Interior Bureau of Reclamation. (1998).

[6] US crops army’s Hydrological Engineer center HEC-RAS River Analysis System User's Manual version 5.0 Feb. 2016

\section{AUTHOR PROFILE}

Mrunal M. Joshi received B.E. (Civil) and M-Tech degrees in Civil Engineering from Pune University in 2001\& 2006 respectively. She is working as Assistant Professor in NBN Sinhgad Engineering College. She has 12 years teaching experience \& received Best Teacher Award. She is pursuing Ph.D from Savitribai Phule Pune University. 